\title{
MANTIS STRUMARIA.
}

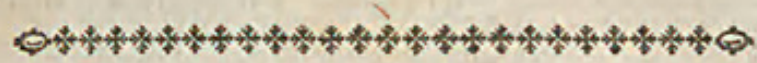

\section{CHARACTER GENERICUS.}

Caput nutans, maxillofum, palpis inftructum. Antenne (plerifque) fetaceæ. Ale quatuor, membranaceæ, (plerifque) convolutæ; inferiores plicatæ.

Pedes antici compreffi, fubtus ferrato-denticulati, armati ungue folitario et digito fetaceo laterali articulato. Poftici quatuor, læves, grefforii.

Thorax linearis, elongatus, anguftatus.

$$
\text { Lin. Syft. Nat. p. } 68 \mathrm{~g} .
$$

CHARACTER SPECIFICUS, Ec.

MANTIS thorace utrinque membranaceo-dilatato obcordato.

Lin. Syft. Nat. p. $6 g 1$.

Roef. inf. 2. gryll. t. 3 .

Mer. Sur. 27. t. 27 .

Cum anteactis temporibus, fabulis et erroribus immerfa jaceret veritas, non defuere qui hujufmodi infecta folia efle quafi animata firmiter credididerint. Notabilis admodum eft thorax permagnus et dilatatus. Alæ inferiores 
feriores pellucidæ funt, levifimo tantum virore tinctx. Americam Auftralem incolit fingulare hoc animalculum.

Fig. I, Pupa, feu infectum adhuc imperfectum.

Fig. 2, Imago, feu infectum declaratum. 



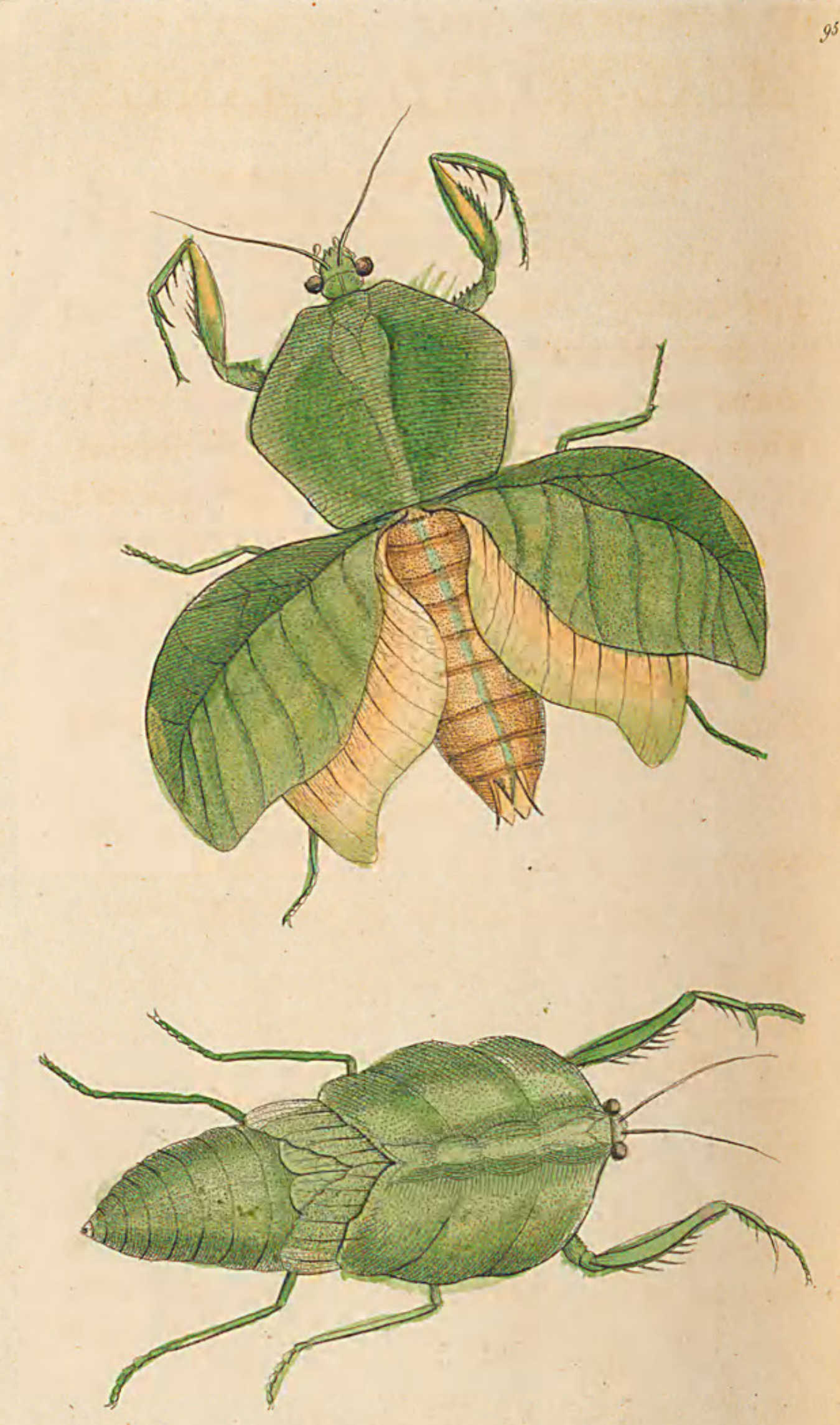

S.1

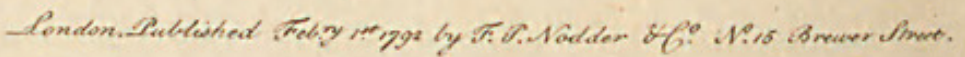




\section{BROAD-BREASTED MANTIS.}

Q

\section{GENERIC CHARACTER.}

Head unfteady: Mouth armed with jaws, and furnifhed with palpi.

Antenne fetaceous, (fome few fpecies excepted.) Wings four, membranaceous, in moft fpecies convoluted: the lower ones (generally) plicated. Feet anterior compreffed, ferrated beneath, armed with a lateral folitary claw and jointed procefs; pofterior four, fmooth, formed for walking.

Thorax (in moft fpecies) elongated and narrowed.

SPECIFIC CHARACTER, छेC.

MANTIS with the fides of the thorax nearly membranaceous and greatly dilated.

Mer. Sur. t. 27.

Roef. 2. gryll. t. 3 .

The Mantis Strumaria is amongft the number of thofe infects which in lefs enlightened times bave been confidered as a kind of animated leaves. The very large, dilated thorax in this infect is highly remarkable.

The 
The lower wings are of a tranfparent appearance, and have but a flight caft of green. This curious animal is a native of South America.

Fig. $\mathbf{I}$, The infect in its pupa ftate.

Fig. 2, The infect in its complete ftate. 


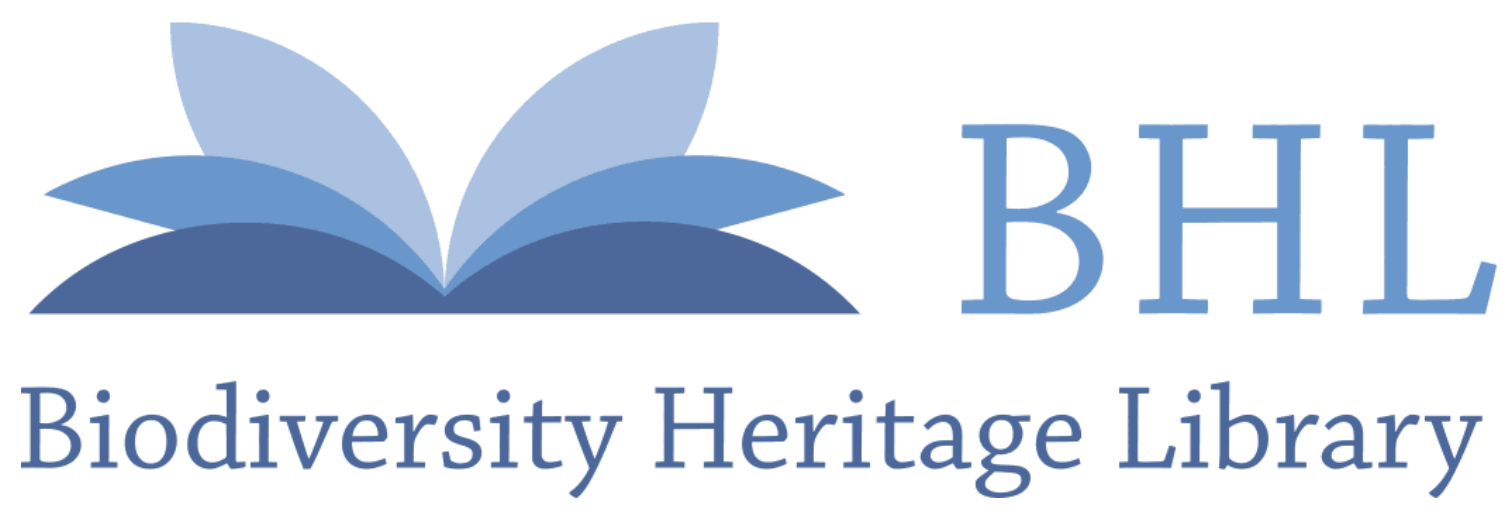

Shaw, George. 1792. "The Broad-Breasted Mantis, Mantis strumaria [PI. 95]." The Naturalist's Miscellany 3(XXXI), https://doi.org/10.5962/p.304515.

View This Item Online: https://www.biodiversitylibrary.org/item/279090

DOI: https://doi.org/10.5962/p.304515

Permalink: https://www.biodiversitylibrary.org/partpdf/304515

\section{Holding Institution}

Museums Victoria

\section{Sponsored by}

Atlas of Living Australia

\section{Copyright \& Reuse}

Copyright Status: Public domain. The BHL considers that this work is no longer under copyright protection.

This document was created from content at the Biodiversity Heritage Library, the world's largest open access digital library for biodiversity literature and archives. Visit BHL at https://www.biodiversitylibrary.org. 